\title{
The analysis of emergency medicine professionals' occupational anxiety during the COVID-19 pandemic
}

\author{
Canan Akman ${ }^{1}$, Murat Cetin ${ }^{2, \star}$, Cetin Toraman ${ }^{3}$
}

${ }^{1}$ Çanakkale Onsekiz Mart University, Faculty of Medicine, Emergency Department, Çanakkale, Turkey

2 İzmir Tınaztepe University, Vocational School, First Aid and Emergency Department, İzmir, Turkey

${ }^{3}$ Çanakkale Onsekiz Mart University, Faculty of Medicine, Medical Education, Çanakkale, Turkey

\section{*Correspondence}

muratcetinn@gmail.com

(Murat Cetin)

\begin{abstract}
Objectives: People worldwide have experienced anxiety during the COVID-19 pandemic including healthcare professionals. News about the number of deaths and cases shared on social media has also increased the anxiety. Anxiety is described as an emotional state in which a feeling of weakness is experienced during preparation for perceived risk; it also includes fear. In our study, the occupational anxiety levels of emergency medicine professionals were compared based on various variables (institution, years of experience, number of daily emergency patient cases in the institution, etc.).

Methods: The study was conducted with 168 emergency medical professionals from 5 different countries. The COVID-19 outbreak was ongoing while data was being collected, and the study was approved by the Clinical Research Ethics Committee provided that the data were collected online. Research data were obtained in June, July, and August 2020. One of the two sub-factors in the scale is physical, physical, and life anxiety factor. There are 12 items in this sub-factor: The lowest possible score is 12 , and the highest score is 60 . The other sub-factors are the work environment, employees, equipment, and environmental factors.

Results: Accessibility to personal protective equipment during the COVID-19 pandemic caused a difference in bodily, physical, and vital anxiety levels $(P<0.05)$. Gender, chronic disease before COVID-19 status, marital status, years of experience, overtime work during the COVID-19 pandemic, and SARS-COV-2 contagion status during the treatment process did not cause any difference in bodily, physical, and vital anxiety levels $(P>0.05)$. The place of work caused a significant difference in the level of bodily, physical, and vital anxiety $(P<0.05)$. Years of experience in the profession caused a significant difference in the level of anxiety regarding work atmosphere, employee, PPE, and environmental factors $(P<0.05)$. During the COVID-19 pandemic, overtime work during the COVID-19 pandemic caused a significant difference in the level of anxiety related to work atmosphere, employee, equipment, and environmental factors $(P<0.05)$. Conclusions: During the COVID-19 pandemic, the emergency service working hours caused a significant difference in the anxiety levels related to work atmosphere, employees, equipment, and environmental factors. During the COVID-19 pandemic, access to personal protective equipment caused a difference in anxiety levels. As a result, the anxiety level of the emergency medicine professionals who are in the front line in the hospitals should be treated, and they should be provided psychological and behavioural support.
\end{abstract}

\section{Keywords}

Emergency medicine; Occupational anxiety; COVID-19

\section{Introduction}

COVID-19 first occurred in Wuhan, the capital of city of Hubei region in China, in December 2019. It is a new type of coronavirus (SARS-COV-2) that belongs to the coronavirus family and causes COVID-19 disease. However, there are no cures for this infection, and it has rapidly spread worldwide.
SARS-COV-2 was declared a "pandemic" by the World Health Organization (WHO) on March 11, 2020 [1]. The COVID-19 pandemic poses a potential risk to the public health because of its high contagiousness and mortality [2]. COVID-19 is contagious, and the death rates can cause people to be psychologically uncomfortable. Likewise, it has been shown that the fear of getting COVID-19 infection is associated with the 
rate of infection, the rate of disease, and the mortality rate [3]. Unlike other disasters, the treatment process is not known in a pandemic. Thus, anxiety can be increased due to compromised safety of healthcare professionals, the risk for their health and their families, performing the duties in a risky environment, working in high-risk departments such as emergency services and intensive care units, and being exposed to social isolation [4].

Healthcare professionals have used every means available to provide emergency assistance in this period of uncertainty. Emergency services are organized by increasing their support and have been restructured. OSHA (Occupational Safety and Health Administration) stated that healthcare workers are in the very high-risk group to get infected with COVID-19 [5]: Those working at the closest distance against COVID-19 infection are healthcare professionals [6]. During the COVID-19 pandemic, all people have experienced anxiety including healthcare professionals. News about the number of deaths and cases shared on social media has also increased the anxiety. Anxiety is an emotional state in which a feeling of weakness is experienced during preparation for perceived risk; it also includes fear.

Anxiety is a process that needs to be managed because it has a negative impact on human life [7]. Emergency physicians are at the forefront of the management of COVID-19 infection and are also vulnerable to the adverse mental health effects that occur due to this infection [8-10]. In this tragic process, it is necessary to improve the understanding of the level of anxiety that emergency medicine professionals have during the COVID-19 pandemic. Studies have shown that emergency medicine specialists are in direct contact with COVID-19 prediagnosis and COVID-19 cases, which increases their anxiety [9]. Strategic plans to prevent anxiety should be formed and implemented immediately. Training on crisis management is given to emergency medicine professionals working in the emergency department, but it is necessary to prevent anxiety as well. Psychological support units should be established where emergency medicine specialists can express their fears and concerns directly. They should also have easy access to these units. Techniques to cope with anxiety should be taught. Likewise, infection control practices and PPE should be provided for emergency medicine professionals to feel safe against COVID-19 infection [11]. This study aims to analyse the occupational anxiety of emergency medicine professionals working in the emergency department during the COVID-19 pandemic according to various variables (institution, year of experience, number of patients in emergency service per day in the institution, etc.).

\section{Methods}

\subsection{Research design}

This study is descriptive research.

\subsection{Participants and data collection}

The research was conducted with the permission of the Ministry of Health COVID-19 Research and Çanakkale Onsekiz Mart University Clinical Research Ethics Committee (KAEK27/2020-E.2000064037). The COVID-19 pandemic was on- going while the data was being collected. The research was approved by the Clinical Research Ethics Committee on condition that the data be collected online. Therefore, the measurement tool was transferred to Google Forms. The participants were first asked whether they consented to participate in the research after they read the information about the research. Other questions in the measurement tool were opened to the ones who consented to participate. The participants who did not consent to participate were not allowed to see the other questions in the scale, and the form was closed. Thus, the we enrolled 168 emergency medicine professionals.

Thus, no sampling method (random, stratify etc.) with known probability could be used. Since participation in this research was carried out with the consent and on a voluntary basis, the research sample became a purposive sample, and the data could not be obtained from the entire population [10]. In purposive sampling, the data are collected from the people that can be easily reached within the period of research instead of seeking participants from the whole population (all emergency medicine professionals in Turkey). Obtaining data from experts who volunteered to participate in the research can still offer data and enable researchers to collect data. This situation reduced the generalizability of the research data to the general population (all emergency physicians). Research data were obtained during June, July, and August 2020. Table 1 indicates the participant characteristics.

\subsection{Data collection tool}

In the study, the occupational anxiety of emergency medicine professionals was obtained using the "Occupational Anxiety Scale for Emergency Medical Service Professionals" developed by Sevinç et al. [9]. The scale is a Likert-type scale that consists of 22 items, has two sub-factors, and determines the participants' reactions to the items on a five-point scale: strongly disagree, 1; disagree, 2; partially agree, 3; agree, 4; strongly agree, 5; One of the two sub-factors in the scale is the bodily, physical, and life anxiety (BPLA) factor. There are 12 items in this sub-factor: The lowest score that can be obtained is 12 , and the highest is 60 . The other sub-factor is work atmosphere, employees, equipment, and environmental factors (WEEE) factor. There are 10 items in this sub-factor: The lowest score that can be obtained is 10 and the highest is 50 . The Cronbach Alpha reliability coefficient gives information about the reliability of the scale in terms of internal consistency and is 0.922 for the BPLA factor, 0.866 for the WEEE factor, and 0.914 for the whole scale. In addition, confirmatory factor analysis (CFA) was applied to the scale. The CFA fit index of the scale is $\mathrm{X} 2 / \mathrm{sd}=3,132 ; \mathrm{GFI}=0.862 ; \mathrm{AGFI}=0.803$; $\mathrm{NFI}=$ $0.851 ; \mathrm{IFI}=0.899 ; \mathrm{CFI}=0.892 ;$ and $\mathrm{RMSEA}=0.077$.

\subsection{Statistical analysis}

Data analysis was in line with research questions. Descriptive analyses such as arithmetic mean, mode, median, standard deviation were applied, and comparison tests were conducted as related to the variables of gender, marital status, seniority, etc. Comparison analysis led to parametric and nonparametric analysis. Parametric statistical analysis requires certain assumptions. The most important of these is the normal 
TA B L E 1. Participant characteristics.

\begin{tabular}{|c|c|c|c|}
\hline Variable & $f(\%)$ & Variable & $f(\%)$ \\
\hline Gender & & Chronic Disease before COVID-19 Pandemic & \\
\hline Female & $54(32.1)$ & No & $135(80.4)$ \\
\hline Male & $114(67.9)$ & Yes & $33(19.6)$ \\
\hline Marital Status & & Place of Work & \\
\hline Single & $30(17.9)$ & University Hospital & $28(16.7)$ \\
\hline Married & $126(75)$ & Education and Research Hospital (State) & $119(70.8)$ \\
\hline Divorced & $12(7.1)$ & Private Hospital & $21(12.5)$ \\
\hline Country & & Years of Professional Experience & \\
\hline Turkey & $155(92.3)$ & $0-5$ Years & $20(11.9)$ \\
\hline Iran & $1(0.6)$ & 6-10 Years & $63(37.5)$ \\
\hline India & $10(6)$ & 11-15 Years & $49(29.2)$ \\
\hline Singapore & $1(0.6)$ & 16-20 Years & $19(11.3)$ \\
\hline South Korea & $1(0.6)$ & 21 Years and Over & $17(10.1)$ \\
\hline $\begin{array}{l}\text { Active Duty of Dealing with COVID-19 } \\
\text { patients at Hospital }\end{array}$ & & $\begin{array}{l}\text { Interventional Treatment to the patients with } \\
\text { COVID-19+ in Emergency Department }\end{array}$ & \\
\hline No & $7(4.2)$ & No & $22(13.1)$ \\
\hline Yes & $161(95.8)$ & Yes & $146(86.9)$ \\
\hline $\begin{array}{l}\text { Overtime Work during the COVID-19 Pan- } \\
\text { demic }\end{array}$ & & $\begin{array}{l}\text { Personal Protective Equipment (PPE) Accessi- } \\
\text { bility Status in COVID-19 Pandemic }\end{array}$ & \\
\hline 0-8 Hours & $28(16.7)$ & No, Insufficient & $20(11.9)$ \\
\hline 8-12 Hours & $49(29.2)$ & Not Sure & $17(10.1)$ \\
\hline 12-24 Hours & $91(54.2)$ & Yes, Sufficient & $131(78)$ \\
\hline $\begin{array}{l}\text { Extra Duty Outside Emergency Service } \\
\text { during the COVID-19 Pandemic }\end{array}$ & & $\begin{array}{l}\text { SARS-COV-2 Contagion Status During Treat- } \\
\text { ment Process }\end{array}$ & \\
\hline No & $127(75.6)$ & No & $93(55.4)$ \\
\hline Pandemic Polyclinic & $33(19.6)$ & Yes & $11(6.5)$ \\
\hline Other & $8(4.8)$ & Not known, Not tested & $64(38.1)$ \\
\hline $\begin{array}{l}\text { Emergency Department Visits per Day (Av- } \\
\text { erage) }\end{array}$ & & Previous Pandemic Experience & \\
\hline $0-100$ & $17(10.1)$ & No & $137(81.5)$ \\
\hline $101-300$ & $18(10.7)$ & Yes & $31(18.5)$ \\
\hline $301-600$ & $40(23.8)$ & & \\
\hline $601-1000$ & $51(30.4)$ & & \\
\hline $1001+$ & $42(25)$ & & \\
\hline
\end{tabular}

distribution of the data of the variables (occupational anxiety level) to be compared [12]. Therefore, the "KolmogorovSmirnov Normal Distribution Test" [12-15] was applied to the scores obtained from the "Occupational Anxiety Scale for Emergency Medical Service Professionals". As a result, the significance value showed that the data did not fit the normal distribution $(P<0.05)$. Thus, a Mann-Whitney U Test was used to compare the differences between the groups (twogroup comparative tests), and Kruskal-Wallis Test was used for three and more group tests in comparison analysis.

\section{Results}

Participant responses to the "Occupational Anxiety Scale for Emergency Medical Service Professionals" were examined. The results are shown in Table 2. Descriptive statistics of occupational anxiety scale applied to emergency medicine professionals showed that the anxiety levels are close to each other and high (both in Turkey and abroad) in terms of "Possibility of exposure to verbal violence while providing the service", "Risk of infection", "Workload", and "Understrength (Shortage of Staff)". The emergency medicine professionals in Turkey are more anxious than their colleagues who work abroad in terms of "Life threatening risks of the job", "uncertainty", 
and "Unethical behaviour encountered during the service"; the anxiety levels related to other items on the scale were determined to be moderate.

Bodily, physical, and vital anxiety levels of emergency medicine professionals were compared according. A MannWhitney U Test was used when the main feature for comparison formed two groups such as gender. When three or more groups were formed (e.g., marital status), the comparison used the Kruskal-Wallis Test (Table 3). Gender, chronic disease before COVID-19 status, marital status, years of experience, overtime work during the COVID-19 pandemic, and SARSCOV-2 contagion status during the treatment process did not cause any difference in bodily, physical, and vital anxiety levels $(P>0.05)$. Place of work caused a significant difference in the level of bodily, physical, and vital anxiety $(P<0.05)$. According to the Nonparametric Dunn-Bonferroni Multiple Comparison test, the bodily, physical, and vital anxiety levels of emergency medicine professionals working in the education research hospitals and the state hospital were higher than those working in private hospitals.

Accessibility to personal protective equipment (PPE) during the COVID-19 pandemic caused a difference in bodily, physical, and vital anxiety levels $(P<0.05)$. According to the Nonparametric Dunn-Bonferroni Multiple Comparison test, the bodily, physical, and vital anxiety levels of emergency medicine professionals who think that PPE is insufficient are higher than those who think it is sufficient. According to the Nonparametric Dunn-Bonferroni Multiple Comparison test, the number of patients who applied to the emergency department per day in the hospital where they were employed caused a difference in the level of bodily, physical, and vital anxiety $(P$ $<0.05)$. Vital anxiety levels are lower for emergency medicine professionals at hospitals with $0-100$ patient visits than the ones who work in the hospital with 301-600,601-1000, or 1001 and more patient visits per day.

The emergency medicine professionals' anxiety levels about the work atmosphere, employees, equipment, and environmental factors were compared according to their differences. A Mann-Whitney U Test was used when the main feature for comparison formed two groups such as gender. When three or more groups were formed (e.g., marital status), the comparison used the Kruskal-Wallis Test (Table 3). The results are shown in Table 4. Gender, chronic disease before COVID-19 pandemic status, marital status, place of work, and emergency department visits per day did not cause a difference in the level of anxiety regarding work atmosphere, employee, PPE, or environmental factors $(P>0.05)$. Years of experience in the profession caused a significant difference in the level of anxiety regarding work atmosphere, employee, PPE and environmental factors $(P<0.05)$. According to the Nonparametric Dunn-Bonferroni Multiple Comparison test, the anxiety levels of emergency medicine professionals with $0-5$ years of professional experience are higher than those with 16-20 years of professional experience.

Accessibility to PPE during the COVID-19 pandemic caused a significant difference in the level of anxiety related to work atmosphere, employees, PPE and environmental factors $(P<0.05)$. According to the Nonparametric Dunn-Bonferroni Multiple Comparison test, emergency medicine professionals who thought that PPE is insufficient have higher levels of anxiety about work atmosphere, employee, equipment, and environmental factors.

During the COVID-19 pandemic, overtime work during the COVID-19 pandemic caused a significant difference in the level of anxiety related to work atmosphere, employee, equipment, and environmental factors $(P<0.05)$. According to the Nonparametric Dunn-Bonferroni Multiple Comparison test, the anxiety levels of the emergency medicine professionals who work 0-8 hours are lower than the ones who work 12-24 hours including the environment, staff, equipment, and environmental factors.

SARS-COV-2 contagion status during treatment process caused a significant difference in the level of anxiety regarding work atmosphere, employee, equipment, and environmental factors $(P<0.05)$. According to the Nonparametric DunnBonferroni Multiple Comparison test, the anxiety levels of the emergency medicine professionals infected with the SARSCOV-2 virus are lower than those who do not know whether they are infected with the virus or have not tested in terms of the work environment, employees, equipment, and environmental factors.

\section{Discussion}

Emergency medicine professionals who work in the emergency department are at the forefront in the fight against the most severe forms of COVID-19 infection both in our country and all over the world. The pandemic process created by this infection causes emergency medicine professionals to have different processes in terms of the workflow at the hospital, during the management of patients, and after contact with patients. During this process, emergency medicine professionals learned about the correct use of PPE and the management of patients. The SARS-COV-2 virus load in the respiratory tract of patients puts emergency medicine professionals at risk because the disease is closely related to pulmonary involvement. Since the beginning of the COVID19 pandemic, passive sharing of information via social media (Twitter, WhatsApp, Facebook) via messages, case discussions, and experiences has created a basis for sharing among their physicians [8, 17, 18]. Information sharing regarding COVID-19 infection was made rapidly with groups of emergency medicine professionals. The most effective measures were taken against this infection, and communication networks were established with the regions affected by the severity of the COVID-19 infection. For example, the emergency medicine association of Turkey is divided into regions and established a fast communication network to share knowledge and experiences with all paediatric emergency medicine professionals in Turkey. This spread information about COVID-19 infection and helped spread awareness. Similarly, an information and communication network were rapidly established in line with the experiences of faculty members from abroad. In a study conducted with academic emergency medicine professionals, it was found that the greatest measure of anxiety and stress relief of the participants was to have PPE [19]. COVID-19 infection poses a risk to all healthcare professionals. The guidelines issued by the Ministry of Health and General Di- 
TA B L E 2. Emergency medicine professionals' occupational anxiety levels.

Turkey $(n=155)$

Turkey $(\mathrm{n}=155)$

$\bar{x}$ (S.D.) Median
Iran/India/Singapore/ South Korea $(n=13)$

Being unable to perform my job duties efficiently due to physical activities as I get $3.65(1.19) \quad 4 \quad 2.23$ (1.42) $\quad 2$ older

Physical load required by the service

Risk of accident while providing the service

Risk of injury while providing the service

Risk of death while providing the service

Possibility of exposure to physical violence while providing the service

Possibility of exposure to verbal violence while providing the service

Reduced income due to permanent disability

Life threatening risks of my job

Uncertainty that my job has

Risk of infection

Exposure to secondary accidents

Other people interfering with my work during treatment

Workload

Understrength (shortage of staff)

Unethical behavior encountered during the service

Lack of knowledge and skills of my colleagues

Patients' and patient relatives' prejudice against us

$\begin{array}{llll}3.99(1.09) & 4 & 3.15(1.28) & 3 \\ 3.70(1.16) & 4 & 2.54(1.19) & 3 \\ 3.34(1.18) & 3 & 2.00(1.08) & 2 \\ 3.62(1.18) & 4 & 2.23(1.48) & 2 \\ 4.51(0.80) & 5 & 3.46(1.51) & 4 \\ \mathbf{4 . 7 5 ( 0 . 6 8 )} & 5 & \mathbf{4 . 1 5 ( 1 . 2 8 )} & 5 \\ 3.49(1.25) & 3 & 2.77(1.30) & 3 \\ \mathbf{4 . 0 1 ( 1 . 0 6 )} & 4 & \mathbf{2 . 8 5 ( 1 . 1 4 )} & 3 \\ \mathbf{4 . 0 0 ( 1 . 1 5 )} & 4 & \mathbf{2 . 3 8 ( 1 . 0 4 )} & 2 \\ \mathbf{4 . 3 7 ( 0 . 8 7 )} & 5 & \mathbf{4 . 0 0 ( 1 . 0 0 )} & 4 \\ 3.93(1.06) & 4 & 3.00(1.23) & 3 \\ 3.63(1.14) & 4 & 3.15(1.07) & 3 \\ \mathbf{4 . 5 2 ( 0 . 7 3 )} & 5 & \mathbf{3 . 7 7 ( 1 . 3 0 )} & 4 \\ \mathbf{4 . 3 4 ( 0 . 9 1 )} & 5 & \mathbf{3 . 6 9 ( 1 . 1 1 )} & 4 \\ \mathbf{4 . 2 1 ( 0 . 9 8 )} & 5 & \mathbf{2 . 6 2 ( 1 . 2 6 )} & 2 \\ 3.23(1.21) & 3 & 2.54(1.27) & 2 \\ 4.27(0.94) & 5 & 3.77(1.01) & 4 \\ 3.38(1.26) & 3 & 2.85(1.07) & 3\end{array}$
action

The need for rapid treatment of the patient and patient transport procedures

$3.89(1.04) \quad 4 \quad 3.38(1.50) \quad 4$

Obstacles to be experienced during patient transport (narrow corridor, etc.)

$3.27(1.29) \quad 3 \quad 2.46(1.33)$

$3.34(1.14) \quad 3 \quad 2.31(1.03)$
Median

3

3

2

2

4

5

3

3

2

4

3

3

4

4

2

2

4

3

2

3 rectorate of Public Health emphasized that the contamination against healthcare workers would be prevented only by having PPE [20].

Although COVID-19 infection has a lower mortality rate than severe acute respiratory syndrome (SARS) and Middle East Respiratory Syndrome coronavirus (MERS), its contagiousness and infectivity is higher [21]. The healthcare of emergency medicine professionals is based on having personal protective equipment against the risk of personal contamination. Our study reveals that without PPE emergency medicine professionals develop anxiety towards the work atmosphere, employees, equipment and environmental factors. It is critical for most healthcare professionals to wear PPE. Despite this, a study conducted by Centre for Disease Control and Prevention (CDC) in China found that 3.8\% (1.716) of the healthcare professionals were infected with the COVID-19 virus: $14.8 \%$ (247) of them were severe cases, and 5 people died [22]. Insufficient PPE can cause physiological and psychological anxiety in healthcare professionals [23, 24]. In our study, accessibility to PPE by emergency medicine professionals increased the level of physical and vital anxiety.

Intubation or some problems with the protective equipment during invasive procedures can increase the anxiety of emergency medicine professionals. Studies carried out that COVID-19 infection affects the lives of healthcare professionals both psychologically and physically, and problems with anxiety primarily involve emergency medicine professionals [25]. In a study conducted by Zhu et al. with 79 healthcare professionals, the anxiety rate in the fight against the COVID19 pneumonia epidemic was reported as $11.4 \%$ [26]. A study by Çalışkan et al. reported that the use of a checklist for the diagnosis of infection, gender, marital status, title, duration of work in the emergency service, chronic diseases, place of work, and infection negatively affected the anxiety score [25].

Our study shows that gender, chronic diseases, marital status, year of experience, overtime work during the COVID-19 Pandemic, and SARS-COV-2 contagion status during treatment process did not cause any difference in the level of bodily, physical, and vital anxiety. However, from an institutional perspective, the anxiety level was found to be higher in emergency medicine professionals working in state and education and research hospitals. The level of anxiety is lower in emergency medicine professionals working in private hospitals. Thus, state, education, and research hospitals have more patients than private hospitals. They also have more exposure to verbal and physical violence, an insufficient number of the staff, and 
TA B L E 3. Comparison of bodily, physical, and vital concerns of emergency medicine professionals according to different variables (Mann-Whitney U Test, Kruskal-Wallis Test).

\begin{tabular}{|c|c|c|c|c|}
\hline Variable & & $\bar{x}(\mathbf{S})$ & Median (Min-Max) & $\boldsymbol{P}$ \\
\hline & 1. Female & $5446.64(10.91)$ & $48(12-60)$ & \\
\hline Gender & 2. Male & $11446.26(9.57)$ & $47.5(17-60)$ & 0.618 \\
\hline Chronic Disease before COVID-19 & 1.No & $13546.04(10.28)$ & $46(12-60)$ & \\
\hline Pandemic & 2.Yes & $3347.73(8.69)$ & $49(35-60)$ & 0.554 \\
\hline & 1.Single & $3047.47(8.09)$ & $49(25-60)$ & \\
\hline Marital Status & 2.Married & $12646.71(10.23)$ & $48(12-60)$ & 0.068 \\
\hline & 3.Divorced & $1240.17(10.31)$ & $41(18-60)$ & \\
\hline & 1.University Hospital & $2844.71(12.63)$ & $47.5(17-60)$ & 0.004 \\
\hline Place of Work & 2.Education and Research Hospital (State) & $11947.90(8.78)$ & $49(12-60)$ & $2>3$ \\
\hline & 3.Private Hospital & $2139.95(10.07)$ & $36(25-60)$ & \\
\hline & 1.0-5 Years & $20 \quad 45.7(9.71)$ & $47.5(26-60)$ & \\
\hline & 2.6-10 Years & $6347.06(10.55)$ & $49(12-60)$ & \\
\hline Years of Experience & $3.11-15$ Years & $4947.86(8.76)$ & $47(31-60)$ & 0.052 \\
\hline & 4.16-20 Years & $1940.63(8.99)$ & $43(25-60)$ & \\
\hline & $5.21+$ Years & $1746.76(11.31)$ & $49(18-59)$ & \\
\hline PPE Accessibility Status in COVID-19 & 1. No, Insufficient & $2053.55(6.01)$ & $55(41-60)$ & 0.001 \\
\hline Pandemic & 2. Not Sure & $1747.65(6.61)$ & $50(35-59)$ & $\mathbf{1}>\mathbf{3}$ \\
\hline & 3. Yes, Sufficient & $13145.11(10.38)$ & $46(12-60)$ & \\
\hline Overtime Work during the COVID-19 & 1.0-8 Hours & $2845.32(8.56)$ & $46(28-60)$ & \\
\hline Pandemic & 2.8-12 Hours & $4946.59(10.65)$ & $49(17-60)$ & 0.625 \\
\hline & 3.12-24 Hours & $9146.58(10.11)$ & $47(12-60)$ & \\
\hline SARS-COV-2 Contagion Status During & $1 . \mathrm{No}$ & $93 \quad 46.12(9.95)$ & $47(17-60)$ & \\
\hline Treatment Process & 2.Yes & $1146.55(10.47)$ & $45(27-59)$ & 0.946 \\
\hline & 3. Not known, Not tested & $6446.72(10.11)$ & $49(12-60)$ & \\
\hline Emergency Department Visits per Day & $1.0-100$ & $1736.82(11.11)$ & $35(17-60)$ & 0.002 \\
\hline (Average) & $2.101-300$ & $1845.67(10.27)$ & $44.5(28-60)$ & $\mathbf{1}<\mathbf{3}$ \\
\hline & $3.301-600$ & $40 \quad 49.3(9.09)$ & $51.5(18.60)$ & $\mathbf{1}<\mathbf{4}$ \\
\hline & $4.601-1000$ & $5147.31(8.10)$ & $48(28-60)$ & $\mathbf{1}<\mathbf{5}$ \\
\hline & 5.1001 and over & $4246.62(10.39)$ & $47.5(12-60)$ & \\
\hline
\end{tabular}

an increased risk of contagion-these factors in turn affect the anxiety levels of emergency medicine professionals. Thus, Turkish medical professionals were largely anxious. The point that distinguishes the professionals in Turkey from emergency medicine professionals abroad is the vital risks brought about by the procedures performed, the uncertainty, and the unethical behaviours encountered while providing services. All of these increase the level of anxiety on emergency medicine professionals.

Eight-hour shifts are preferred in emergency services, but 24-hour shifts are possible. There may be problems in the diagnosis and treatment due to fatigue [27]. The anxiety level was high among the emergency medicine professionals whose emergency service working hours were 12-24.
In many studies, being young, having semi-work experience, and intense work predisposes one to burn-out in tertiary care hospitals [28]. In another study conducted in China, excessive burn-out was observed in doctors working in the emergency department in tertiary hospitals with less than 10 years of experience [30]. Our study also correlates with these results. During the pandemic, emergency medicine professionals with less professional experience were more anxious due to the atmosphere, employees, equipment, and environmental factors.

The emergency medicine professionals working in emergency department and serving the society $24 / 7$ are like a safety net. During the COVID-19 pandemic, they worked in emergency services with innovative solutions by synthesizing up- 
T A B L E 4. The comparison of emergency medicine professionals' anxiety levels according to different variables/work atmosphere, equipment, and environmental factors (Mann-Whitney U Test, Kruskal-Wallis Test).

\begin{tabular}{|c|c|c|c|c|c|}
\hline Variables & & $\mathbf{n}$ & $\bar{x}(\mathbf{S})$ & Median (Min-Max) & $P$ \\
\hline \multirow{2}{*}{ Gender } & 1.Female & 54 & $37.91(8.65)$ & $37(19-50)$ & \multirow{2}{*}{0.505} \\
\hline & 2.Male & 114 & $37.31(7.03)$ & $37(20-50)$ & \\
\hline Chronic Disease before COVID-19 & 1.No & 135 & $37.39(7.39)$ & $37(20-50)$ & \multirow{2}{*}{0.603} \\
\hline Pandemic & 2.Yes & 33 & $37.94(8.37)$ & $41(19-50)$ & \\
\hline \multirow{3}{*}{ Marital Status } & 1.Single & 30 & $37.87(8.09)$ & $36.5(23-50)$ & \multirow{3}{*}{0.264} \\
\hline & 2.Married & 126 & $37.83(7.10)$ & $38(20-50)$ & \\
\hline & 3.Divorced & 12 & $33.17(10.05)$ & $33.5(19-50)$ & \\
\hline \multirow{3}{*}{ Place of Work } & 1.University Hospital & 28 & $37.07(7.60)$ & $39.5(21-50)$ & \multirow{3}{*}{0.111} \\
\hline & 2.Education and Research Hospital (State) & 119 & $38.26(7.26)$ & $37(20-50)$ & \\
\hline & 3.Private Hospital & 21 & $33.76(8.41)$ & $35(19-48)$ & \\
\hline \multirow{5}{*}{ Years of Experience } & 1.0-5 Years & 20 & $40.75(7.44)$ & $42(23-50)$ & 0.020 \\
\hline & 2.6-10 Years & 63 & $38.16(6.97)$ & $38(21-50)$ & \multirow[t]{4}{*}{$1>4$} \\
\hline & 3.11-15 Years & 49 & $37.96(7.35)$ & $37(20-50)$ & \\
\hline & 4.16-20 Years & 19 & $33.16(8.73)$ & $33(19-50)$ & \\
\hline & 5.21 Years and over & 17 & $34.76(7.09)$ & $33(22-50)$ & \\
\hline Personal Protective Equipment (PPE) & 1. No, Insufficient & 20 & $44.9(5.03)$ & $44(33-50)$ & 0.001 \\
\hline Accessibility Status in COVID-19 & 2. Not Sure & 17 & $39.24(5.22)$ & $40(29-50)$ & $\mathbf{1}>\mathbf{3}$ \\
\hline Pandemic & 3. Yes, Sufficient & 131 & $36.15(7.47)$ & $36(19-50)$ & \\
\hline Overtime Work during the COVID-19 & 1.0-8 Hours & 28 & $34.68(6.14)$ & $33(22-50)$ & 0.031 \\
\hline \multirow[t]{2}{*}{ Pandemic } & 2.8-12 Hours & 49 & $37.45(6.88)$ & $37(21-50)$ & \multirow[t]{2}{*}{$\mathbf{1}<\mathbf{3}$} \\
\hline & 3.12-24 Hours & 91 & $38.4(8.15)$ & $39(19-50)$ & \\
\hline \multicolumn{2}{|c|}{ SARS-COV-2 Contagion Status During 1.No } & 93 & $37.08(7.41)$ & $36(20-50)$ & 0.027 \\
\hline \multirow[t]{2}{*}{ Treatment Process } & 2.Yes & 11 & $33.09(5.17)$ & $33(23-41)$ & \multirow[t]{2}{*}{$\mathbf{2}<\mathbf{3}$} \\
\hline & 3. Not known, Not tested & 64 & $38.88(7.86)$ & $39.5(19-50)$ & \\
\hline Emergency Department Visits per Day & $1.0-100$ & 17 & $31.65(9.01)$ & $30(19-48)$ & \multirow{5}{*}{0.066} \\
\hline \multirow[t]{4}{*}{ (Average) } & $2.101-300$ & 18 & $38.39(6.96)$ & $37.5(22.50)$ & \\
\hline & $3.301-600$ & 40 & $37.28(7.13)$ & $36.5(22.50)$ & \\
\hline & 4.601-1000 & 51 & $38.18(6.52)$ & $39(20-50)$ & \\
\hline & 5.1001 and over & 42 & $38.88(8.01)$ & $38(25-50)$ & \\
\hline
\end{tabular}

to-date information about COVID-19 infection while ensuring the survival of their patients. Using professional behavioural health resources with mechanisms that can be accessed at an early stage to emergency medicine professionals and other healthcare professionals during the pandemic process may reduce their anxiety level [31,32].

\section{Conclusions}

Emergency medicine professionals who work long hours as a result of close contact with patients who are diagnosed with COVID-19 infection are anxious. During the pandemic, the anxiety faced by the emergency medicine professionals who are at the forefront of the hospitals is an important problem that needs to be resolved immediately. In this process, we believe that the necessary psychological and behavioral support should be given to emergency medicine professionals to cope with the anxiety that they experience.

\section{Limitations}

There are a few limitations to this research First, the relative transmission rate of the SARS-COV-2 virus in the northern hemisphere decreased when the data were obtained. Even though the number of patients decreased slightly, all healthcare professionals, especially emergency medicine specialists, were tired. In fact, we wanted to conduct a survey that would represent all emergency physicians. Although the transmission 
rate of the disease decreased relatively, people continued to avoid congregation. The permission of the ethics committee could not be obtained to allow face-to-face application. Thus, we used online data collection, but few people filled the data collection tool and provided a return. Most of the responses were from Turkey. Thus, the results not be generalizable.

\section{AUTHOR CONTRIBUTIONS}

Canan Akman, Murat Cetin and Cetin Toraman designed the study. Canan Akman and Murat Cetin collected the data. Canan Akman and Cetin Toraman analyzed the results and drafted the manuscript.

\section{ETHICS APPROVAL AND CONSENT TO PARTICIPATE}

The research was conducted with the permission of the Ministry of Health COVID-19 Research and Çanakkale Onsekiz Mart University Clinical Research Ethics Committee (KAEK27/2020-E.2000064037).

\section{ACKNOWLEDGMENT}

Thanks to all the peer reviewers and editors for their opinions and suggestions.

\section{FUNDING}

None.

\section{CONFLICT OF INTEREST}

The authors declare that there is no conflict of interest regarding the publication of this article.

\section{DATA AVAILABILITY}

The data used to support the findings of this study are available from the corresponding author upon request.

\section{REFERENCES}

[1] Sakaoğlu HH, Orbatu D, Emiroglu M, Çakır Ö. COVID-19 Salgını Sırasında Sağlık Çalışanlarında Spielberger Durumluk ve Sürekli Kaygı Düzeyi:Tepecik Hastanesi Örneği. Tepecik Eğit. ve Araşt. Hast. 2020; 30: 1-9. (In Turkish)

[2] Stuijfzand S, Deforges C, Sandoz V, Sajin C, Jaques C, Elmers J, et al. Psychological impact of an epidemic/pandemic on the mental health of healthcare professionals: a rapid review. BMC Public Health. 2020; 20: 1230.

[3] Ahorsu DK, Lin CY, Imani V, Saffari M, Griffiths MD, Pakpour AH. The fear of COVID-19 Scale: development and initial validation. International Journal of Mental Health and Addiction. 2020; 1-9.

[4] Maunder RG. Was SARS a mental health catastrophe? General Hospital Psychiatry. 2009; 31: 316-317.

[5] Türk Toraks Derneği Mesleksel Akciğer Hastalıkları Çalışma Grubu (2020). Sağlık çalışanlarında covıd-19 salgını sırasında mesleki riskler hakkında bilgilendirme ve öneriler. 2020. Avaliable at: httpss.// toraks . org. tr/halk/news . aspx?detail=5768 (Accessed: 24 July 2020).
[6] Guidance on Preparing Workplaces for COVID-19. Avaliable at: https://www osha.gov/Publications/OSHA3990. pdf (Accessed: 27 May 2020).

[7] Aktan E. Sosyal Medya ve Sosyal Kaygı: Sosyal Medya Kullanıcıları Üzerine Bir Araştırma. Selçuk Üniversitesi. 2018; 11: 35-53. (In Turkish)

${ }^{[8]}$ Liu Y, Yang Y, Zhang C, Huang F, Wang F, Yuan J, et al. Clinical and biochemical indexes from 2019-nCoV infected patients linked to viral loads and lung injury. Science China Life Sciences. 2020; 63: 364-374.

[9] Lai J, Ma S, Wang Y, Cai Z, Hu J, Wei N, et al. Factors associated with mental health outcomes among health care workers exposed to coronavirus disease 2019. JAMA Network Open. 2020; 3: e203976.

[10] Shanafelt TD, Boone S, Tan L, Dyrbye LN, Sotile W, Satele D, et al. Burnout and satisfaction with work-life balance among US physicians relative to the general us population. Archives of Internal Medicine. 2013; 172: $1377-1385$.

[11] Amin F, Sharif S, Saeed R, Durrani N, Jilani D. COVID-19 pandemicknowledge, perception, anxiety and depression among frontline doctors of Pakistan. BMC Psychiatry. 2020; 20: 459.

[12] Mull CC, Bowman WR. A call to restore your calling: self-care of the emergency physician in the face of life-changing stress: part 5 of 6 : physician burnout. Pediatric Emergency Care. 2020; 36: e25-e29.

[13] Larry B, Johnson BR,Turner LA. Research Methods, Design, and Analysis. 2014.

[14] Postacı ES, Uysal İ,Koşan AMA, Toraman Ç. Acil Sağlık Çalışanları İçin Mesleki Kaygı Ölçeğinin Geliştirilmesi. Tıp Eğitimi Dünyası. 2020; 19: 102-115. (In Turkish)

[15] Özdamar K. Paket programlar ile istatistiksel veri analizi. Eskişehir: Nisan kitabevi. 2013. (In Turkish)

[16] Büyüköztürk Ş. Sosyal Bilimler İçin Veri Analizi El Kitabı. Ankara: Pegem Akademi. 2013. (In Turkish)

[17] Green SB, Salkind NJ. Using SPSS for Windows and Macintosh. Analyzing and understanding the data. USA: Pearson Prentice Hal. 2008.

[18] Kalaycı Ş. SPSS uygulamalı çok değişkenli istatistik teknikleri. Ankara: Asil Yayın Dağıtım. 2005. (In Turkish)

[19] Clavier T, Ramen J, Dureuil B, Veber B, Hanouz JL, Dupont H, et al. Use of the smartphone app WhatsApp as an e-learning method for medical residents: multicenter controlled randomized trial. JMIR mhealth uhealth. 2019; 7: e12825.

[20] Demailly Z, Brulard G, Selim J, Compère V, Besnier E, Clavier T. Gender differences in professional social media use among anaesthesia researchers. British Journal of Anaesthesia. 2020; 124: e178-e184.

[21] Rolls K, Hansen M, Jackson D, Elliott D. How health care professionals use social media to create virtual communities: an integrative review. Journal of Medical Internet Research. 2016; 18: e166.

[22] Rodriguez RM, Medak AJ, Baumann BM, Lim S, Chinnock B, Frazier R, et al. Academic emergency medicine physicians' anxiety levels, stressors, and potential stress mitigation measures during the acceleration phase of the COVID-9 pandemic. Academic Emergency Medicine. 2020; 27: 700707.

[23] Çetintepe SP, Ilhan MN. COVID-19 Salgınında Saglık Çalısanlarında Risk Azaltılmasi. Journal of Biotechnology and Strategic Health Research. 2020; 1: 50-54. (In Turkish)

[24] Liu Y, Gayle AA, Wilder-Smith A, Rocklöv J. The reproductive number of COVID-19 is higher compared to SARS coronavirus. Journal of Travel Medicine. 2020; 27: taaa021.

[25] Wu Z, McGoogan JM. Characteristics of and important lessons from the coronavirus disease 2019 (COVID-19) outbreak in China: Summary of a report of 72314 cases from the Chinese center for disease control and prevention. JAMA. 2020; 323: 1239.

[26] Maynard SL, Kao R, Craig DG. Impact of personal protective equipment on clinical output and perceived exertion. Journal of the Royal Army Medical Corps. 2016; 162: 180-183.

[27] Martín Rodríguez F, Fernández Pérez C, Castro Villamor M, Martín Conty JL, Arnillas Gómez P, Casado Vicente V. Does level D personal protective equipment guard against hazardous biologic agents during cardiopulmonary resuscitation? Emergencias. 2018; 30: 119-122.

[28] Song W, Li H, Ding N, Zhao W, Shi L, Wen D. Psychometrics properties of the Team Interaction Scale and influencing factors of team interaction of tertiary hospital physicians in China: a cross-sectional study. BMJ Open. 2019; 9: e026162. 
[29] Zhu J, Sun L, Zhang L, Wang H, Fan A, Yang B, et al. Prevalence and influencing factors of anxiety and depression symptoms in the firstline medical staff fighting against COVID-19 in Gansu. Frontiers in Psychiatry. 2020; 11: 386.

[30] Wang Z, Xie Z, Dai J, Zhang L, Huang Y, Chen B. Physician burnout and its associated factors: a cross-sectional study in Shanghai. Journal of Occupational Health. 2014; 56: 73-83.

[31] Cui G, Wang F, Xu Y. Job burnout among physicians in ten areas of China. Zhonghua Yi Xue Za Zhi. 2013; 93: 3773-3775. (In Chinese)

[32] Tatebe LC, Rajaram Siva N, Pekarek S, Liesen E, Wheeler A, Reese
$\mathrm{C}$, et al. Heroes in crisis: trauma centers should be screening for and intervening on posttraumatic stress in our emergency responders. Journal of Trauma and Acute Care Surgery. 2020; 89: 132-139.

How to cite this article: Canan Akman, Murat Cetin, Cetin Toraman. The analysis of emergency medicine professionals' occupational anxiety during the COVID-19 pandemic. Signa Vitae. 2021;17(3):103-111. doi:10.22514/sv.2021.023. 